$\underline{\xi}=-m$

\title{
Ameilorative effect of lycopine against cisplatin toxicity in rats
}

\author{
Fatma Elgendey ${ }^{1}$ *, Rania M. Waheed ${ }^{2}$, Samar S. Ibrahim ${ }^{2}$, Alshaimaa M Said ${ }^{3}$, Faten I. Elsayed ${ }^{4}$ \\ ${ }^{1}$ Deparment of Animal Wealth Development (Genetic and Genetic Engineering) \\ Faculty of Veterinary Medicine, Benha University, Egypt \\ ${ }^{2}$ Department of Forensic Medicine and Toxicology, Faculty of Veterinary Medicine, Benha University, Egypt \\ ${ }^{3}$ Department of Biochemistry Faculty of Veterinary Medicine, Benha University, Egypt \\ ${ }^{4}$ Department of pharmacology Department Faculty of Veterinary Medicine, \\ Benha University, Egypt, Moshtohor, Toukh 13736, Qalyubia, Egypt \\ *Corresponding author E-mail: Fatenibrahim73@yahoo.com
}

\begin{abstract}
The following study aimed to investigate the hepato and neuro protective efficacy of Lycopine against Cisplatin which induced hepatotoxicity and neurotoxicity. Twenty Five male Wister rats were used for this experiment they were equally divided into 5 groups $(5$ rats per group): group (1) served as control group they were injected $1 \mathrm{ml}$ saline orally once daily for 20 day, group (2) served as Corn Oil group and they were administrated $1 \mathrm{~mL}$ Corn Oil orally once daily for 20 days, group (3) served as Lycopine group and they were administrated (10 mg/kg b.wt) Lycopine orally once daily for 20 days. , group (4) served as Cisplatin treated group and they were injected (6 mg/kg b.wt.) intrapertonialy once at day 10 of experiment and group (5) Lycopine+Cisplatin group and were administrated $10 \mathrm{mg} / \mathrm{kg}$ b.wt Lycopine orally once daily for 20 days and injected $6 \mathrm{mg} / \mathrm{kg}$ b.wt.) intraperitonialy once at day 10 . Result revealed that Cisplatin induced liver damage indicated by significant increase in liver biomarkers ALP, AlT, AST along with significant decrease in albumin, Moreover marked increase increase in tissue concentrations of malondialdehyde(MDA) and Total antioxidant(TAC) and reduce tissue Glutathione reductase(GSH),that indicated oxidative stress Also results revealed up regulation IL-6 and down regulation IL-10 in liver and brain tissue in compared to control group. However, interestingly concurrent adminsteration of the Lycopine orally at dose level of $10 \mathrm{mg} / \mathrm{kg}$ b.wt for 20 days with Cisplatin can mitigate these toxic effects caused by Cisplatin.So it is concluded that the antioxidant and the anti-inflammatory effects of Lycopine moderate the Cisplatin-induced hepato and neurotoxicity.
\end{abstract}

Keywords: Cisplatin; Lycopine; Liver,Brain.

\section{Introduction}

Cisplatin is an important anticancer drug. It kills cancer cells via various modes of actions beginning from oxidative stress, reactive oxygen species production, lipid peroxidation and activation of pro-inflammatory cytokines. These mechanisms of action may be an important way in the strategy of prevention of its side effects on normal cells Faten et al. 2021, On other way it as a useful and effective drug in the treatment of many solid tumors, in other side it has many hazard effects including hepatotoxicity; sever kidney injury, ototoxicity and cardiac toxicity Gaskell et al .2018.

Cisplatin destroys cell membrane and rise free oxygen and hydroxyl radicals and as a result of this and induces lipid peroxidation, inflammation and hypoxia Dhillon et al .2019. Cisplatin-induced hepatotoxicity is associated to oxidative damage and mitochondrial dysfunction Nagla and Basma (2017).

Antioxidants are substances used in breaking down reactive oxygen species (ROS) in food accordingly, many synthetic antioxidants have been used in nutrition caused harmful effects due to instability, and there is a hope to use antioxidant compounds from plant sources safe for clinical applications. These metabolites have been used to not only their antioxidant properties but also they have been proven to have anti-tumor, anti-inflammatory, nociceptive, hepatoprotective and nephroprotective effects Rjeibi et al.2017 and Lourenço (2019).

Lycopine is a phytochemical mainly found in tomato and tomato-based products. It is a tetraterpene compound consisting of eight isoprene units and 11 double linear bonds. Lycopine is a non-pro-vitamin A carotenoid Yin et al.2019. Lycopine is the most strong antioxidant. It is an important deactivator of ROS. For instance, it can remove singlet oxygen two and ten times more than beta-carotene and vitamin E Przybylska et al.2020. Now there has been more interest in Lycopine's health benefits. It is not only a potent antioxidant; its beneficial effects in the prevention and treatment of a different diseases Joshi et al.2020

The health effects of Lycopine may be related to the antioxidant effects of the native trans or Cisplatin structures and shortened by derivatives such as lycopineopenals, lycopineopenols, and lycopineopenoic acids Urbonaviciene and Viskelis 2017.

Lycopine is a natural neuroprotective agent. It seems that this carotenoid contributes to cognitive longevity Crowe-White et al .2019. and the treatment of several neuronal diseases, including cerebral ischemia, Parkinson's disease (PD), Alzheimer's disease (AD), subarachnoid haemorrhage, epilepsy, Huntington's disease, and depression Chen et al.2019. Therefore, in the current study, we focused on evalu- 
ating the protective effects of Lycopine against Cisplatin-induced hepatic and brain injury in rats at both Molecular study and biochemical levels. However, hepatotoxicity is also encountered during low-dose repeated Cisplatin therapy Gedik et al. 2017.

In recent studies it has been reported that the mechanism of Cisplatin-induced hepatotoxicity can be multifactorial. Oxidative stress resulting from ROS may have a major role among these factors Veiga et al. 2020

\section{Material and methods}

\subsection{Tested drugs:}

Cisplatin (cytoplastin-50 $0^{\circledR}$ ) sterile solution, vial contains $50 \mathrm{ml}$ of $50 \mathrm{mg}(50 \mathrm{mg} / 50 \mathrm{ml})$ Cisplatin. It was obtained from cipla company, Egypt. Cisplatin was administrated at a dose of $6 \mathrm{mg} / \mathrm{kg}$ b.wt intraperitonealy (IP) once according to (Ammar et al. 2013). Lycopine (Lycopine 5mg®) was obtained from puritans pride premium, USA. It was administrated at a dose of $10 \mathrm{mg} / \mathrm{kg}$ b.wt orally in corn oil once daily for 20 days according to (Sönmez et al. 2011)

\section{2. Experimental rats:}

The present study was carried out on a total number of 25 white Wister albinos male rats weighting $150-170$ gm. Rats were obtained from Center of Laboratory Animal, Faculty of Veterinary Medicine, Benha University, Egypt. They acclimatized for one week prior to the experiment. All rats received standard laboratory balanced commercial diet and water ad libitum.

\section{3. Experimental design and treatment protocol:}

Twenty five male wistar rats were divided randomly into 5 groups ( 5 animals per group).

Group I :Rats in this group were served as control group and were administrated orally $1 \mathrm{~mL}$ saline once daily for 20 days.

Group 2: Rats in this group were served as corn oil group and were administrated orally $1 \mathrm{~mL}$ corn oil once daily for 20 days.

Group 3: Rats in this group were served as Lycopine group and were administrated orally (10 $\mathrm{mg} / \mathrm{kg}$ b.wt) Lycopine once daily for 20days.

Group 4: Rats in this group were served as Cisplatin treated group and were injected $(6 \mathrm{mg} / \mathrm{kg}$ b.wt.) intrapertonialy once at day 10 of experiment.

Group 5: Rats in this group were served as Lycopine+Cisplatin group and were administrated orally (10 mg/kg b.wt) Lycopine once daily for 20 days and injected (IP) $(6 \mathrm{mg} / \mathrm{kg}$ b.wt.), once at day 10

\subsection{Blood sampling}

Blood samples were collected by puncture of retro orbital plexus from 5 rats in each group after the end of the experiment . Blood sample was collected without anticoagulant for separation of clear serum for biochemical analysis. These serum samples were used for biochemical analysis of (ALT, AST,ALp and albumin).

\subsection{Tissue samples}

At the end of the experiment all rats were scarified, and tissue samples were taken from liver and brain for both biochemical oxidative stress markers ( MDA,TAC and GSH) and gene expression (IL-10 and IL-6).

\subsection{Assay methods:}

Serum biochemical analysis:

Serum was collected from blood after centrifugation at $3000 \mathrm{rpm}$ for $10 \mathrm{~min}$ at $4{ }^{\circ} \mathrm{C}$. Serum serum alanine aminotransferase (ALT), aspartate aminotransferase (AST), alkaline phosphatase(ALP) were detected .The absorbance of ALT,ALP and AST was read at $505 \mathrm{~nm}$ and the enzyme activity was calculated as U/L. ALT and AST were estimated according to Safety Data Sheet (2002) And albumin was estimated using a commercially available kit (Quimica Clinica Aplacada, Tarragona, Spain). All procedures were performed according to the manufacturer's instructions. Oxidative status was done by determination of the activity of Total Antioxidant activity (TAC), malondialdehyde (MDA), and glutathione reductase(GSH) levels according toKoracevic et al. (2001).) and Beutler et al. (1963) respectively

Preparation of liver homogenates: The tissue was dissected and washed with a PBS (phosphate buffered saline) solution, $\mathrm{pH} 7.4$ containing $0.16 \mathrm{mg} / \mathrm{ml}$ heparin to remove any red blood cells and clots. One gram of each tissue was homogenized in $5 \mathrm{ml}$ of $5-10 \mathrm{ml}$ cold buffer (i.e., $50 \mathrm{mM}$ potassium phosphate, pH7.5 1mM EDTA) per gram tissue, using sonicator homogenizer. Aliquots of tissue homogenates was centrifuged by cooling centrifuge $4000 \mathrm{rpm}$ for $20 \mathrm{~min}$ then stored at $-20^{\circ} \mathrm{Ctill}$ do biochemical analysis.

Kits

For estimating ALT, AST, and ALP were supplied by Centronic GmbH Company

Germany by chem7, Kits for estimating of of Total Antioxidant activity (TAC),malondialdehyde (MDA), and glutathione reductase(GSH) in liver homogenate were purchased from BioDiagnostic Company, Cairo, Egypt by spectro nanodrop. Genes expression was made using High Capacity cDNA Reverse Transcription Kit (Applied Biosystems, CA, USA), and SYBR green master (Applied Biosystems, CA, USA).

Genes expression by real time PCR:

Total RNA was isolated from liver and brain tissue using the Total RNA Isolation System (Promega Co., Madison, WI, USA) according to the manufacturer's protocol. Briefly, RNA was extracted and re-suspended in $50 \mu \mathrm{L}$ RNase free water, then stored at $-80{ }^{\circ} \mathrm{C}$. The total RNA concentration was determined spectrophotometrically (SPECTRO star Nano, BMG Labtech Co., Ortenberg, Germany) and then 1 $\mu \mathrm{g}$ of RNA was used for cDNA synthesis using the High Capacity cDNA Reverse Transcription Kit (Applied Biosystems, CA, USA). The condition was achieved in line with the kit of cDNA reverse transcription as follow; step I $\left(10 \mathrm{~min} / 25^{\circ} \mathrm{C}\right)$, step II $\left(120 \mathrm{~min} / 37^{\circ} \mathrm{C}\right)$, step III $\left(5 \mathrm{~min} / 85^{\circ} \mathrm{C}\right)$ and step IV $\left(\infty \sim\right.$ at $\left.4{ }^{\circ} \mathrm{C}\right)$, then, $1 \mu \mathrm{g}$ of the obtained cDNA with the SYBR green master mix were used in a total of 
$20 \mu \mathrm{l}$ reaction volume $7 \mu \mathrm{l}$ of nuclease-free water, $10 \mu \mathrm{l}$ of master mix, $1 \mu \mathrm{l}$ of forward primer, $1 \mu \mathrm{l}$ of reverse primer, and $1 \mu \mathrm{l}$ of DNA template) for HSP70 and $\beta$-actin gene amplification using the following primers:

IL 6 Forward GACTTCCAGCCAGTTGCCTTCTTG, IL 6

Reverse TGGTCTGTTGTGGGTGGTATCCTC, IL 10 Forward TGCCAAGC CTTGTCAGAAATGATCAAG, IL 10 Reverse TGCCAAGCCTTGTCAG AAATGATCAAG. GAPDH 5'-AACTCCCA TTCCTCCACCTT-3' forward, 5'GAGGGCCTCTCTCTTGCTCT-3' reverse..

The genes were amplified then the expression levels were analyzed using a real-time PCR (7500 Fast Real-Time PCR System, Applied Biosystems, CA). The cycling condition was justified first the initial activation $\left(3 \mathrm{~min} / 95^{\circ} \mathrm{C}\right)$, denaturation $\left(3 \mathrm{~s} / 95^{\circ} \mathrm{C}\right)$, annealing/ extension $\left(30 \mathrm{~s} / 60^{\circ} \mathrm{C}\right)$, and the number of cycles were 40 according to (Zhao FJ etal 2009). All gene expression level was normalized against the GAPDH gene.

\subsection{Statistical analysis}

The results were done as mean \pm SE of the experimental groups using (one-way ANOVA) followed by Duncan's multiple range test. All analysis was performed by Statistical Package for Social science Software (SPSS (16) software (SPSS Inc., Chicago, USA).

\section{Results}

\subsection{Effect on liver biomarker}

Results revealed that intrapertonial injection of Cisplatin at dose of $6 \mathrm{mg} / \mathrm{kgb}$.wt once at day 10 showed significantly increased in ALP, ALTand AST by compared to control and corn oil group as well as significant decrease in albumin level,while interestingly it was found that concurrent adminsteration of Lycopine with Cisplatin result in significant in their levels ., also albumin return to normal level . all these data illustrated in table (1)

\subsection{Effect on oxidative stress biomarker}

The malondialdehyde (MDA) significantly increased by Cisplatin than control and corn oil group and grossly decreased by Lycopine with Cisplatin .Total anti-oxidant (TAC) increased by Cisplatin and down by given Lycopine with Cisplatin. Reduced glutathione GSH level reduced by Cisplatin and increased again by Lycopine with Cisplatin .Table (2)

\subsection{Effect on gene expression}

It was found that the expression of IL6 significantly increased in liver and brain tissue by Cisplatin than control and corn oil group and by the action of Lycopine genes expression regained to normal levels . IL10 down regulated in liver and brain tissue of Cisplatin group than what's happen in control group and corn oil group, while beneficially concurrent adminsteration of Lycopine with Cisplatin leads to upregulation of genes expression again Table (3),(4)

Table 1: Effect of Lycopine on ALP, ALT, AST Concentration in Serum (IU/L) and Albumin Mg/ in Cisplatin Treated Rats. Data are Presented As $($ Mean \pm S.E). S.E $=$ Standard Error. Mean Values with Different Superscript Letters in the Same Column Are Significantly Different at $(\mathrm{P}<0.05)$

\begin{tabular}{|c|c|c|c|c|c|}
\hline Groups & $\mathrm{N}$ & $\begin{array}{l}\text { Mean } \pm \text { Std. Error } \\
\text { ALP(U/L) }\end{array}$ & ALT(U/L) & $\mathrm{AST}(\mathrm{U} / \mathrm{L})$ & Albumin $(\mathrm{g} / \mathrm{dl})$ \\
\hline Control & 5 & $320.1 \pm 1.63^{\mathrm{e}}$ & $48.67 \pm 1.3^{\mathrm{e}}$ & $89.56 \pm 1.58^{c}$ & $2.93 \pm 0.23^{\mathrm{a}}$ \\
\hline corn oil & 5 & $308.1 \pm 1.49^{c}$ & $90.9 \pm 2.3^{c}$ & $93.57 \pm 2.03^{\mathrm{c}}$ & $2.97 \pm 0.26^{\mathrm{a}}$ \\
\hline Lycopine & 5 & $543.54 \pm 0.83^{\mathrm{c}}$ & $85.1 \pm 1.37^{\mathrm{d}}$ & $93.13 \pm 3.13^{\mathrm{c}}$ & $2.26 \pm 0.11^{\mathrm{b}}$ \\
\hline Cisplatin & 5 & $999.7 \pm 0.70^{\mathrm{a}}$ & $209.9 \pm 1.37^{\mathrm{a}}$ & $222.8 \pm 1.05^{\mathrm{a}}$ & $0.98 \pm 0.33^{c}$ \\
\hline lycopine + Cisplatin & 5 & $602.63 \pm 2.07^{\mathrm{b}}$ & $102.27 \pm 0.72^{\mathrm{b}}$ & $128.55 \pm 1.95^{\mathrm{b}}$ & $2.08 \pm 0.06^{\mathrm{b}}$ \\
\hline
\end{tabular}

Table 2: Effect of Lycopine on MDA, TAC and GSH Activity (Nmol/Ml) in Cisplatin Treated Rats. Data are Presented as (Mean \pm S.E). S.E $=$ Standard Error. Mean Values with Different Superscript Letters in the Same Column are Significantly Different at $(\mathrm{P}<0.05)$

\begin{tabular}{|c|c|c|c|c|}
\hline Groups & $\mathrm{N}$ & $\begin{array}{l}\text { Mean } \pm \\
\text { Std. Error } \\
\text { MDA(nmol/gm) }\end{array}$ & $\mathrm{TAC}(\mu \mathrm{mol} / \mathrm{g})$ & $\mathrm{GSH}(\mathrm{U} / \mathrm{gm})$ \\
\hline Control & 5 & $125.35 \pm 1.45^{\mathrm{d}}$ & $24.78 \pm 1.6^{\mathrm{a}, \mathrm{b}}$ & $135.2 \pm 1.21^{\mathrm{a}}$ \\
\hline corn oil & 5 & $130.57 \pm 1.2^{\mathrm{c}}$ & $22.5 \pm 1.3^{\mathrm{b}}$ & $99.64 \pm 1.16^{\mathrm{b}}$ \\
\hline Lycopine & 5 & $115.41 \pm 1.82^{\mathrm{e}}$ & $17.4 \pm 1.87^{\mathrm{c}}$ & $134.7 \pm 1.06^{\mathrm{a}}$ \\
\hline Cisplatin & 5 & $504.8 \pm 1.59^{\mathrm{a}}$ & $27.09 \pm 1.43^{\mathrm{a}}$ & $87.97 \pm 1.08^{c}$ \\
\hline lycopine + Cisplatin & 5 & $298.83 \pm 0.81^{\mathrm{b}}$ & $21.06 \pm 0.67^{\mathrm{b}, \mathrm{c}}$ & $137.4 \pm 1.57^{\mathrm{a}}$ \\
\hline
\end{tabular}

Table 3: Effect of Lycopene on Fold Change in the Gene Expressions of IL6 and IL10 in Liver in Cisplatin Treated Rats. Data are Presented as (Mean \pm S.E). S.E $=$ Standard Error. Mean Values with Different Superscript Letters in the Same Column are Significantly Different at $(\mathrm{P}<0.05)$

\begin{tabular}{llll}
\hline Groups & Mean \pm Error of the gene expression in liver & IL10 \\
& $\mathrm{N}$ & IL6 & $1.01 \pm 0.005^{\mathrm{c}}$ \\
Control & 5 & $1.05 \pm 0.022^{\mathrm{b}}$ & $1.38 \pm 0.05^{\mathrm{b}}$ \\
corn oil & 5 & $1.02 \pm 0.06^{\mathrm{b}}$ & $1.4 \pm 0.15^{\mathrm{b}}$ \\
Lycopine & 5 & $0.98 \pm 0.03^{\mathrm{b}}$ & $0.77 \pm 0.114^{\mathrm{d}}$ \\
Cisplatin & 5 & $2.43 \pm 0.20^{\mathrm{a}}$ & $2.96 \pm 0.03^{\mathrm{a}}$ \\
lycopine+Cisplatin & 5 & $1.28 \pm 0.08^{\mathrm{b}}$ & \\
\hline
\end{tabular}


Table 4: Effect of Lycopene on Fold Change in the Gene Expressions of IL6 and IL10 in Brain in Cisplatin Treated Rats. Data are Presented as (Mean \pm S.E). S.E = Standard Error. Mean Values with Different Superscript Letters in the Same Column are Significantly Different at $(\mathrm{P}<0.05$

\begin{tabular}{llcl} 
S.E). S.E = Standard Error. Mean Values with Different Superscript Letters in the Same Column are Significantly Different at (P<0.05 & IL10 \\
\hline Groups & Mean \pm Error of the gene expression in brain & $1.2 \pm 0.07^{\mathrm{b}}$ \\
& $\mathrm{N}$ & IL6 & $1.64 \pm 0.183^{\mathrm{a}, \mathrm{b}}$ \\
Control & 5 & $1.55 \pm 0.132^{\mathrm{c}}$ & $2.1 \pm 0.14^{\mathrm{a}}$ \\
corn oil & 5 & $1.85 \pm 0.14^{\mathrm{b}, \mathrm{c}}$ & $0.49 \pm 0.022^{\mathrm{c}}$ \\
Lycopine & 5 & $2.81 \pm 0.71^{\mathrm{b}, \mathrm{c}}$ & $2.05 \pm 0.37^{\mathrm{a}}$ \\
Cisplatin & 5 & $5.42 \pm 0.30^{\mathrm{a}}$ & $3.03 \pm 0.02^{\mathrm{b}}$ \\
lycopine + Cisplatin & 5 & 3.05 & \\
\hline
\end{tabular}

\section{Discussion}

Cisplatin is one of the most mostly used antitumor drug, however, it may cause liver and brain toxicity that depend on the dose and the duration of the drug administration Dasari and Tchounwou (2014). In the present study, lycopine is used in combination with Cisplatin as an antioxidant and anti-inflammatory agent to ameliorate Cisplatin-induced toxicity.

Cisplatin produced serious array of events of liver injury where significant increase in serum CS produced serious array of events of liver injury where significant increase in serum ALP,ALTand AST significantly increased by Cisplatin than control and corn oil group reach These events were consistent with other studies who confirmed the changes related to the CP induced hepatotoxicity. Waseem et al., (2015) and Hanan et al., (2020) and grossly decreased by Lycopine with Cisplatin. Elevation of serum ALT and AST levels indicator of hepatotoxicity and indirectly reflects the failure of liver function Rabab and Fatma (2019).

Our results appeared to be consistent with many previous findings that indicated a hepatotoxic effect of cisplatin and its association with increased free radical formation and the subsequent oxidative and nitrosative stress. Omar et al.,(2016) In addition, our results appeared to agree with the study by Yousef et al.,(2009) who found increased oxidative stress markers in the liver of cisplatin-treated rats.

Cisplatin. can increase the generation of superoxide anion and NO by iNOS .The co-existence of both radicals forms peroxynitrite, a potent RNS. Both ROS and RNS are capable to activate the intrinsic apoptotic pathway to ultimately cleave Casp-3 Narayanan et al., (2015)

Cisplatin-associated alterations in liver and brain whether biochemical or inflammatory effects are attributed to the induction of cellular oxidative stress and endoplasmic reticulum stress that increase the level of superoxide anions and hydroxyl radicals. Yilmaz (2004). These free radicals can directly react with different cellular components causing their damage, inhibit mitochondrial respiratory chain functions, and increase mitochondrial permeability transition pore leading to ATP depletion and nucleus-independent apoptosis signaling. Dasari and Tchounwou (2014).

Lycopine is a natural pigment, synthesized by plants. Red fruits and vegetables are the most common sources of Lycopine, which had the strongest antioxidant activity among all dietary carotenoids. Therefore, nowadays, the potential role of Lycopine in human health is beginning to be noticed, and the most important health benefits are hypothesized to occur through their ability to protect against oxidative damage Urbonaviciene and Viskelis, P 2017. The aim of the present study was to demonstrate that Lycopine is an effective antioxidant. In this study, it was observed after Lycopine treatment that GSH and albumin level increased while AST, ALT,Alp,TAC and MDA levels decreased The results of Al-Salmi (2019) also revealed that the Administration of lycopine with ACR significantly decreased the ALT, AST and MDA level and increased GSH level when compared to ACR treated group. Jiang et al., (2016) found that treatment with Lycopine is able to inhibit the elevation of liver function markers, and liver damage. Moreover, Lycopine significantly raised GSH and reduced MDA, which suggesting that the activity of Lycopine as antioxidant play a role in the mechanism of its hepatoprotective effect and ameliorative effect against Cisplatin duced hepatotoxicity.

Increase in ROS levels in cells stimulated with Cisplatin. In previous studies on the antioxidant effect of lycopine, lycopine inhibited nitration of proteins and DNA strand breakage caused by peroxynitrite treatment Muzandu et al., (2006) and decreased the oxidative DNA damage caused by the redoxcycling of catechol-estrogens Muzandu et al.,(2005) and Liu et al. (2006) determined the subcellular localization of lycopene in prostate cancer cells and found that $81 \%$ of the lycopene was localized to the nucleus. These results support an antioxidant effect of lycopine in various cells the inhibitory effect of lycopine on Cisplatin-induced activation of interlukin 6 caused by the ROS as the obtained results from our research that Cisplatin causing increase level of the gene expression of IL6 decreased by lycopine.

Cisplatin causing reduction in IL-10 These results may be due to the decline in IL-10 exacerbates hepatic lesion that downregulate proinflammatory cytokine release. Faten et al.,(2021) Koppelman et al., (1997)

IL-10 is an important anti-inflammatory cytokine and plays essential role in controlling immune responses in the intestinal mucosa .It inhibits the synthesis of pro-inflammatory cytokines such as TNF- $\alpha$, IL- $1 \beta$ and IFN- $\gamma$ and blocks NF- $\kappa$ B activation. These results were nearly similar to those reported by El- Shaimaa et al. (2020), who revealed a significant rise in the inflammatory status of the injured colon with decreased levels of IL-10.

IL-10 is an anti-infammatory cytokine that overturns the activation of leukocytes and the production of pro-infammatory cytokines and chemokines (Miller et al., (2010). Deng and colleagues (2001) revealed that the administration of exogenous IL-10 prevents the upregulation of TNF- $\alpha$ and ICAM-1 expression and the infux of neutrophils into the tissues in reply to Cisplatininjection. Nowadays, it has become a strategic approach to use anti-infammatory agents to ameliorate the Cisplatin-induced damage as lycopine.

\section{Conclusion}

It is concluded that lycopine has an ameliorating effect which minimizes the hepatic and neural toxicity induced by cisplatin,

\section{References}

[1] AL-Salmi F.A.(2019): Ameliorative and Synergistic Effect of Red Raspberry and Lycopine against Hepatotoxicity Induced by Acrylamide in Male Mice. International Journal of Pharmacology, 15: 166-76, 2019. https://doi.org/10.3923/ijp.2019.166.176. 
[2] Ammar A, Hadi, Sabah N, and Al T (2013): Evaluation of the Protective Properties of Amlodipine, on Cisplatin Induced Cardiotoxicity in Male Rats Evaluation of the Protective Properties of Amlodipine, on Cisplatinn Induced Cardiotoxicity in Male Rats Evaluation of the Protective Properties of Amlodipine, on Cisplatin Induced Cardiotoxicity in Male Rats. Global Journal of Medical research Interdsciplinary 13: $2249-4618$.

[3] Beutler E, Duron O and Kelly, B.M (1963): Improved method for the determination

[4] Chen, D.; Huang, C.; Chen, Z.(2019): A review for the pharmacological effect of lycopine in central nervous system disorders. Biomed. Pharmacother. 111, 791-801. [CrossRef] https://doi.org/10.1016/j.biopha.2018.12.151.

[5] Crowe-White, K.M.; Phillips, T.A.; Ellis, A.C.(1019): Lycopine and cognitive function. J. Nutr. Sci. 8. [CrossRef] https://doi.org/10.1017/jns.2019.16.

[6] Dasari, S. and Tchounwou PB.(2014): Cisplatin in cancer therapy: Molecular mechanisms of action. Eur J Pharmacol 740:364-78. https://doi.org/10.1016/i.ejphar.2014.07.025.

[7] Deng J, Kohda Y, Chiao H, Wang Y, Hu X, Hewitt SM, Miyaji T, McLeroy P, Nibhanupudy B, Li S, Star RA (2001): Interleukin-10 inhibits ischemic and Cisplatin-induced acute renal injury. Kidney Int 60(6):2118-2128. https://doi.org/10.1046/j.1523-1755.2001.00043.X.

[8] Dhillon, P., Amir, E., Lo, M., Kitchlu, A., Chan, C., Cochlin, S., Yip, P., Chen, E. and Lee, R.,Ng, P., (2019): A case-control study analyzing mannitol dosing for prevention of Cisplatin-induced acute nephrotoxiciy. J. Oncol. Pharm. Pract. : official publication of the International Society of Oncology Pharmacy Practitioners 25, 875-883. https://doi.org/10.1177/1078155218771461.

[9] El-Shaimaa, A., Arafa, Wafaa, R., Mohamed, Dana, M., Zaher, Hany ,A. ,Omar .2020.Gliclazide attenuates acetic acid-induced colitis via the modulation of PPAR $\gamma, \mathrm{NF}-\kappa \mathrm{B}$ and MAPK signaling pathways. Toxicology and Applied Pharmacology, 391 , 114919. https://doi.org/10.1016/j.taap.2020.114919.

[10] Faten I. E.;Fatma, E.; Rania M. W., Mona A. E. (2021): Protective effect of Moringa olifera seed extract on Cisplatin induced nephrotoxicity in rats Int. J. Pharm Pharm. Sci, Vol 13, Issue 5, 78-82. https://doi.org/10.22159/ijpps.2021v13i5.41125.

[11] Gaskell H, Ge Xand Nieto N.(2018): High-mobility group box-1 and liver disease. Hepatol Commun. 2(9):1005-1020. https://doi.org/10.1002/hep4.1223.

[12] Gedik, S., Erdemli, M.E., Gul, M., Yigitcan, B., Gozukara Bag, H., Aksungur, Z., Altinoz, E.,(2017):. Hepatoprotective effects of crocin on biochemical and histopathological alterations following acrylamide-induced liver injury in Wistar rats. Biomed.Pharmaco.. 95, 764-770. https://doi.org/10.1016/j.biopha.2017.08.139.

[13] Hanan M. H. Lamya H Al-Wahaibi, Mohammed A . Yasmen F. M.(2020): Suppression of Cisplatin-Induced Hepatic Injury in Rats Through Alarmin High-Mobility Group Box-1 Pathway by Ganoderma lucidum: Theoretical and Experimental Study Drug Design, Development and Therapy 2020:14 2335-2353 https://doi.org/10.2147/DDDT.S249093.

[14] Jiang W, Guo MH, Hai X. (2016): Hepatoprotective and antioxidant effects of lycopene on non-alcoholic fatty liver disease in rat. World Gastroenterol 2016; 22(46): 10180-10188 [PMID: 28028366 https://doi.org/10.3748/wjg.v22.i46.10180.

[15] Jiang W., MEI-HUA G.and XIN, H., (2016).: Hepatoprotective and antioxidant effects of lycopine on non-alcoholic fatty liver disease in rat, World J. Gastroenterol., 22 (46): 10180-8. https://doi.org/10.3748/wjg.v22.i46.10180.

[16] Joshi, B.; Kar, S.K.; Yadav, P.K.; Yadav, S.; Shrestha, L.; Bera, T.K. (2020): Therapeutic and medicinal uses of lycopine: A systematic review. Int. J. Res. Med Sci. 2020, 8, 1195. [CrossRef] https://doi.org/10.18203/2320-6012.ijrms20200804.

[17] Koppelman B, Neefjes JJ, de Vries JE, de Waal MR. (1997) Interleukin-10 down-regulates MHC class II alpha beta peptide complexes at the plasma membrane of monocytes by affecting arrival and recycling. Immunity. 1997;7(6):861-871. ().https://doi.org/10.1016/S10747613(00)80404-5.

[18] Koracevic, D.; Koracevic, G.; Djordjevic V, Andrejevic, S and Cosic V (2001) Method for the measurement of antioxidant activity in human fluids.J Clin Pathol 54:356-361. https://doi.org/10.1136/jcp.54.5.356.

[19] Liu A, Pajkovic N, Pang Y, Zhu D, Calamini B, Mesecar Al, van Breemen RB (2006) Absorption and subcellular localization of lycopine in human prostate cancer cells. Mol Cancer Ther 5:2879-2885. https://doi.org/10.1158/1535-7163.MCT-06-0373.

[20] Lourenço, S.C.; Moldão-Martins, M.; Alves, V.D. (2019):Antioxidants of natural plant origins: From sources to food industry applications. Molecules 24, 4132. [CrossRef] https://doi.org/10.3390/molecules24224132.

[21] Miller, R.P.;Tadagavadi RK, Ramesh G, Reeves WB (2010) Mechanisms of Cisplatin nephrotoxicity. Toxins (Basel) 2(11):2490-2518. https://doi.org/10.3390/toxins2112490.

[22] Muzandu K, El Bohi K, Shaban Z, Ishizuka M, Kazusaka A, Fujika S (2005) Lycopine and beta-carotene ameliorate catechol estrogen-mediated DNA damage. Jpn J Vet Res 52:173-184.

[23] Muzandu K, Ishizuka M, Sakamoto KQ, Shaban Z, El Bohi K, Kazusaka A, Fujita S (2006) Effect of lycopine and betacarotene on peroxynitritemediated cellular modifications. Toxicol Appl Pharmacol 215:330-340 https://doi.org/10.1016/j.taap.2006.03.006.

[24] Nagla A E. and Basma E. (2017): Proanthocyanidin protects against Cisplatin-induced oxidative liver damage through inhibition of inflammation and NF-jb/TLR-4 pathway. Environmental Toxico. 32:1952-1963. https://doi.org/10.1002/tox.22418.

[25] Narayanan KB., Ali M, Barclay BJ, Cheng Q, D’Abronzo L, Dornetshuber-Fleiss R and Park HH (2015): Disruptive environmental chemicals and cellular mechanisms that confer resistance to cell death, Carcinogenesis, 36: 89- 110. https://doi.org/10.1093/carcin/bgv032.

[26] of blood glutathione. J Lab Clin Med 61:882-888.

[27] Ohkawa H, Ohishi N, Yagi K.(1979): Assay for lipid peroxides in animal tissues by thiobarbituric acid reaction. Anal Biochem 1979;95:351-8. https://doi.org/10.1016/0003-2697(79)90738-3.

[28] Omar HA, Mohamed WR, Arab HH, Arafa el SA. (2016) Tangeretin alleviates Cisplatin-induced acute hepatic injury in rats: targeting MAPKs and apoptosis. PLoS One.;11(3):e0151649. 2014; 66 (6):1050-1059. https://doi.org/10.1371/journal.pone.0151649.

[29] Przybylska, S.(2020): Lycopine-a bioactive carotenoid offering multiple health benefits: A review. Int. J. Food Sci. Technol. 2020,55 , 11-32. https://doi.org/10.1111/ijfs.14260.

[30] Rabab F. H., M.D. and Fatma F. H., M.D (2019): Ameliorative Effect of Lycopine on Acrylamide-Induced Hepatotoxicity in Adult Albino Rats. Med. J. Cairo Univ., Vol. 87, No. 7, December: 4129-41 35. https://doi.org/10.21608/mjcu.2019.76710.

[31] Rjeibia, I. , Anouar, F.,b , Anouar B.: Sana N.c, Jazia S. , Saidia,I. , Souida,S. , Najla H. , Allaguib.M.S.(2017): Phytochemical characterization and bioactivity of Lycopineium europaeum: A focus on antioxidant, antinociceptive, hepatoprotective and nephroprotective effects. Biomed.\& Pharmaco. 95 1441-1450 https://doi.org/10.1016/j.biopha.2017.09.035.

[32] Safety Data Sheet (2002): Sodium metabisulphite. Issued 25.09.2002. pp 1-3 Revision No. 1.

[33] Sönmez M, Türk G, Çeribaş1 AO, Sakin F, and Ateşşahin A (2011): Attenuating effect of lycopine and ellagic acid on 2, 3, 7, 8- tetrachlorodibenzo-p-dioxin-induced spermiotoxicity and testicular apoptosis. Drug and Chemical Toxicology 34: 347-356 https://doi.org/10.3109/01480545.2011.557382.

[34] Urbonaviciene, D.; Viskelis, P. (2017): The Cisplatin-lycopine isomers composition in supercritical CO2 extracted tomato by-products. LWT-Food Sci. Technol. 85, 517-523. [CrossRef] https://doi.org/10.1016/j.lwt.2017.03.034.

[35] Veiga, M.; Costa, E.M.; Silva, S.; Pintado, M. (2020): Impact of plant extracts upon human health: A review. Crit. Rev. Food Sci. Nutr. 2020, 60, 873-886. https://doi.org/10.1080/10408398.2018.1540969.

[36] Waseem M, Bhardwaj M, Tabassum H, Raisuddin S, Parvez S. (2015) Cisplatin hepatotoxicity mediated by mitochondrial stress. Drug Chem Toxicol. 2015; 38: 452-459. https://doi.org/10.3109/01480545.2014.992437.

[37] Yilmaz HR, Iraz M, Sogut S, Ozyurt H, Yildirim Z, Akyol O(2004): The effects of erdosteine on the activities of some metabolic enzymes during Cisplatin-induced nephrotoxicity in rats. Pharmacol Res 50:287-90 https://doi.org/10.1016/j.phrs.2004.03.003.

[38] Yin, Y.; Zheng, Z.; Jiang, Z.(2019): Effects of lycopine on metabolism of glycopineolipid in type 2 diabetic rats. Biomed. Pharmacother. 2019, 109, 2070-2077. [CrossRef] [PubMed] https://doi.org/10.1016/j.biopha.2018.07.100. 
[39] Yousef MI, Saad AA,and El-Shennawy LK. (2009): Protective effect of grape seed proanthocyanidin extract against oxidative stress induced by Cisplatin rats. Food Chem Toxicol. 47(6): 1176-1183 https://doi.org/10.1016/j.fct.2009.02.007.

[40] Zhao FJ, Ma JF, Meharg A.A Grath SP. (2009): Arsenic uptake and metabolism in plants. New Phytol 181:777-94. https://doi.org/10.1111/j.14698137.2008.02716.x. 